\title{
The Ethical Morality of Christianity Requires an Assiduous Pursuit of the Great Commandment
}

\author{
Mark Malmin \\ San Jose State University, San Jose, USA \\ Email: mbmalmin@comcast.net
}

How to cite this paper: Malmin, M. (2022). The Ethical Morality of Christianity Requires an Assiduous Pursuit of the Great Commandment. Open Journal of Social Sciences, 10, 36-56.

https://doi.org/10.4236/jss.2022.101004

Received: November 23, 2021

Accepted: January 7, 2022

Published: January 10, 2022

Copyright $\odot 2022$ by author(s) and Scientific Research Publishing Inc. This work is licensed under the Creative Commons Attribution International License (CC BY 4.0).

http://creativecommons.org/licenses/by/4.0/ (c) (i) Open Access

\begin{abstract}
This humanities style essay-formatted paper exegetically explores foundational biblical principles of Christianity, morality, Christian duplicity, and behaviors found in Christian failures and successful endeavors, particularly as these principles apply to the epistemology of Christian faith, choosing to embrace good over evil, while simultaneously failing at our own flawed human efforts to overcome evil in our thought patterns, which emanate from the (fallen) human heart of mankind. The scope of this paper is not limited to religion because the ethical principles described herein apply to law, philosophy, business, and the sociology of everyday living. The pursuit of truth and honesty impact every area of life. In setting life goals for ourselves and our children on things that matter most, what could be more important than the pursuit of truth? For Christians, this requires the relentless pursuit of truth. What is truth? Jesus said, "I am the way, the truth, and the life. No one comes to the Father except through me." (John 14:6 NKJV) The Christian faith of soteriology is based entirely upon the teachings of Jesus, the Great Commandment, and the teaching of Jesus Christ that all roads don't lead mankind to heaven. The presentation of these issues utilizes personal anecdotal vignettes and commentary by the author.
\end{abstract}

\section{Keywords}

Morality, Law, Ethics, Religion, Spiritual Warfare

\section{Introduction}

From the industrial revolution to agriculture, medicine, automation, and computer technology to aerospace, most of mankind's greatest successes and inventions came from tenacious persistence of human efforts after repeated failures. Evolutionary anthropological success has always been preceded by failure. This 
concept of failure and success is seen throughout the entire Bible. Christianity is filled with examples of failure, success, and redemption. The Bible is no ordinary book. According to The Top 10 Best-selling Books of All Time (2021) at allopeverything.com, the Bible is the best-selling book of all time throughout the world, having sold about 5 billion copies, and it is also the most translated book in human history. This author invites you to read the Bible. It will change your life!

The pursuit of ethical truth and honesty is a shared foundational principle or axiom that is intentionally built into all aspects of human governance, law, science, religion, medicine, and the applied psychology of wellness. The concept of ethics intrinsically incorporates the societal concepts of morality which fosters convivial living, peace, security, and conflict resolution. We see this conceptually in all aspects of life, from parenting all the way into our criminal justice systems, wherein fairness and justice are intended to become part of our governing goal and methodology. Laws are created to protect the social fabric and wellbeing of mankind. Laws are formulated and enacted based on common moral values that people embrace. To a large extent, morality and ethics stem from shared religious beliefs. We can all agree that certain behaviors cannot be allowed or permitted in society. Inherent to truth is the widespread belief that good and evil exist. Out of this belief system come morality and law. Christianity plays a role in these societal mores.

This concept of morality comes from the common belief that murder, rape, stealing of another's property, and an endless list of other human behaviors are prohibited by law. The issue of morality arises out of religious beliefs. We see this in the Ten Commandments, and in the Golden Rule that parents teach their children. The Golden Rule is a societal value that the whole world can embrace. You don't have to be a Christian, Baptist, Catholic, Muslim, or Jew in order to embrace the Golden Rule. The Golden Rule is closely linked in its genesis to the teachings of Jesus, love your neighbor as yourself. Parents, who are not necessarily Christians, can comfortably teach their children to treat other children the way they would want to be treated. If humans didn't believe in both good and evil, it's unlikely that anyone would believe in God, heaven, or hell. Most of the world believes in all of these things. In the real world, both good and evil exist. Heaven and hell are both real. It would be catastrophic for anyone to not take this seriously.

\section{Background Discussion/Understanding Failure}

Anthropological failure analysis allows future endeavors to be recalculated with modifications that can lead to success in all fields of science. This principle applies to our spirituality as well in terms of our learning to overcome our failures. We learn a lot from our own failures and the failure of others.

We see examples of this with something as simple as learning through failure how to bake delicious chicken, after overcooking it the first time. The principle 
of learning from trial and error and research applies to all aspects of learning. If you want to walk on water, you need to understand and embrace the spiritual principle of faith. If you are about to face a metaphorical Goliath-like figure in your life, you need to have warrior-like confidence that you can win if the Lord is on your side and you possess the ability to overcome fear.

These concepts represent principles of spiritual warfare, with goodness and success being an ongoing war of good over evil. We need to carefully choose our battles. We also need to understand that man has always been in a spiritual war against evil. The great apostle Paul, who wrote much of the New Testament, was a former murderer and persecutor of Christians before he met Jesus and got saved. Paul wrote this profound truth: "For we do not wrestle against flesh and blood, but against principalities, against powers, against the rulers of the darkness of this age, against spiritual hosts of wickedness in the heavenly places" (Ephesians 6:12 NKJV). Our real enemy is not our fellow brother, sister, or neighbor. It's Satan!

Failure is not always a bad thing unless it's catastrophic. Some of our best successes begin with failure. Failure promotes learning. This holds true in the spiritual dimension. With God, all things are possible...that is to say, all good things are possible! There are some things that are not spiritually possible, thank the Lord. God cannot lie, beguile, cheat, or trick us into failure because he cannot deny his own character, his promises, his written word, his love, goodness, or his justice. The Word of God stands alone and it embodies Jesus Christ. The Word became flesh and dwelt among us (John 1:1-3,14 KJV). Jesus Christ and his Word are reliable and trustworthy.

When it comes to failure, we can learn from centuries of biblical experience and decades of personal experience that the weak link isn't Jesus. Jesus never fails us; we fail ourselves and others because we haven't learned the right principles of walking in obedience with Christ, and allowing him to guide us into enduring success. The greatest failure Christians seem to have, in my opinion, is that collectively we don't trust Jesus or take him at his word. Years of failure and success teach committed followers of Jesus that he is trustworthy and his promises are reliable and unfailing.

\section{Why Is It Necessary to Examine Failure?}

Failure is a valuable byproduct of testing. Testing is necessary for all human endeavors. It provides a standard for what is acceptable, while it also provides objective, measurable, failure analysis data. Testing measures the breaking points of steel for bridges and airplanes. Would you want your surgeon to not have successfully graduated from medical school simply because the doctor had a very likeable, charming personality? Testing creates passing standards. All of life involves testing; it never ends. You would never know if your child could swim if they had no training and were never introduced to deep water wherein they were tested. The spirit world has testing, too. 
Jesus was led into the wilderness to be tested for 40 days. When Jesus had been without food for 40 days God allowed Satan to test and tempt Jesus. Do you think God will exempt any of us from being tested? All of life is a never-ending series of tests. Failure simply lets us know where improvement is needed. God tested Abraham, who was willing to give God his only son, Isaac. This amazing story in Genesis 22 begins with these words: Now it came to pass after these things that God tested Abraham... (Genesis 22:1). God would arguably not ask this of everyone, because most people couldn't handle such a test, but the Lord knew Abraham would pass this test. The rewards that came with this are astounding (Genesis 22:15-18 NKJV). The takeaway here is that testing is necessary in life for all things, and if God tested Abraham and his own son, Jesus, you can expect that the Lord will test you, too.

Notwithstanding some perspicacious theological exception like the abortion of babies, I am of the opinion no one will enter heaven without having been tested. Failure can be corrected, most sin can be forgiven, tactical engineering failures can be remediated, but the absence of testing is undeniable and inescapable, relatively speaking. Training and preparation for testing can come in various forms, but spiritual testing of an eternal nature comes from the Lord. "The fining pot is for silver and the furnace for gold: but the Lord trieth the hearts" (Proverbs 17:3 KJV).

We learn many things through failure, not the least of which is perseverance to keep trying and do better. Failure teaches us lessons, both practical and spiritual. It helps us to learn and understand what works, and what does not. If we didn't have any understanding of what produces failure, we might think that all plans have a chance of working. Nothing could be further from the truth. The enemy of your soul would have you believe all roads lead to heaven, and this would be the biggest lie one could ever embrace.

Learning what the Lord wants for us and the things he wants us to avoid, comes from trial and error failures, learning to become more honest with ourselves, and from maturation of walking with the Lord and learning to trust him. In order for spiritual efficacy to have a chance, the fully committed follower of Jesus needs to humbly understand that, aside from our potential, we are all born in sin and we lack pure hearts. Scripture states it this way: the heart is deceitful above all things, and desperately wicked: who can know it? (Jeremiah 17:9 KJV). This requires a heart of honesty and humility to acknowledge to ourselves that we don't always want the truth, or seek the truth. Prayer can turn this flawed deadly heart condition completely around, if we sincerely ask God to circumcise our hearts and make our heart pure, in his eyes. We can learn to walk in truth if we seek it, and we can learn to become more successful when we learn how to stop repeating failure. If we don't recognize failure or know what it looks like in practical terms, then we just keep repeating the same mistakes, over and over again, while hoping for a different outcome. The world calls this insanity. 


\section{Why Is Human Failure Unavoidable?}

Because we are born in sin, we have fallen natures. This is the very reason why God's Word states that "all have sinned" and come short of the glory of God (Romans 3:23 KJV). Scripture puts this even more bluntly by stating the human heart is deceitful above all things, and desperately wicked (Jeremiah 17:9 KJV). Even when we want to do the right thing, we don't always know what that would look like, so we need to seek the Lord and not rely on our own understanding or wisdom. We have to apply this principle to every aspect of our lives and our walk with Christ.

There is another interconnecting dimension in learning to walk in truth and have the mind of God. Our whole relationship with Christ is based on the principle of faith. Without faith, it is impossible to please God. "But without faith it is impossible to please him, for he who comes to God must believe that he is and that he is a rewarder of those who diligently seek him" (Hebrews 11:6 KJV). God honors and rewards faith. It's the key that opens doors! We try to walk in faith, and often times we do, but sometimes we make a decision based on a good faith belief, but we subsequently learn that we were wrong in our earlier assumptions. We had faith, but it wasn't the will of God, and we simply errored in our conclusions. This is all part of living and walking with Christ. Good faith mistakes are unavoidable, because life is a journey, and we are learning the hard way, like little children do. And like little children, we don't always want the truth; we want our own way, and sometimes we honestly think that what we want is the right way. But we later see it wasn't. Learning to avoid such mistakes comes with seeking the truth, asking God to give us a pure heart, and his mind and will on what we seek. The application of perseverance, tenacity, and learning to hear the Holy Spirit's voice comes with experience and learning from failure.

\section{Anecdotal Testimonial Faith}

Allow me to provide a couple of anecdotal examples of how God has been faithful and reliable to my family over the years, and by extension, to me. My father, born in 1915, grew up in the tough streets of Chicago during the days of $\mathrm{Al} \mathrm{Ca-}$ pone. During those days of prohibition, alcohol became a big business in Chicago. At a very young age, my father became a raging alcoholic, leading him down a destructive road to where he eventually wanted to commit suicide. One day he began walking toward a bridge in Chicago, intending to jump off the bridge and commit suicide. The pastor of a Christian church was driving in the opposite direction to his church for a board meeting and saw my father out of the corner of his eye. My father was not hitchhiking; he was simply walking toward the bridge. The thought came into the pastor's mind to turn around and "go talk to that man". At first, the pastor did not realize this was the Lord speaking to him, so he kept driving, and ignored the thought. The same thought and exact wording came into his mind again, turn around and go talk to that man. The pastor, quite humorously I might add, began arguing with himself in a soliloquy, that he 
didn't have time for this, because he needed to get to a church board meeting. So, he kept driving. The same thought came to him a third time, and at this point the pastor realized the Lord was guiding him to go and talk to this man.

The pastor made a U-turn, drove back to where my father was walking, and stopped his vehicle beside my father. He rolled down the passenger window and asked my father, can I give you a lift young man? My father accepted his offer and got into the vehicle. A conversation ensued between the two of them, and the pastor learned that my father was planning to commit suicide. The pastor told my father that Jesus loved him, died for him on a cross and that God could change his life and make it meaningful. The pastor led my father to the Lord through prayer, and my father invited Christ into his heart. A miracle then occurred because my father was instantly delivered of alcoholism, with no other intervention or addiction treatment. His deliverance was completely the work and mercy of the Lord. My father's friends and co-workers all thought my dad had lost his mind, because he wouldn't stop talking about Jesus, and they couldn't understand why he didn't want to drink anymore.

A few years after this, my father attended Bible school and eventually became a pastor of church in southern California. I was 7 years old at that time, and my sister was 12. My parents sold their house and spent every dime they had saved to take our family to the jungles of Brazil to become missionaries, and preach the gospel of Jesus Christ. While down there in 1958, my sister, Bonnie, came down with an acute attack of appendicitis. My father prayed for her, asking the Lord to heal her, but her pain persisted. God can and does heal people but oftentimes he uses doctors to help us. Like other good things in life, the science of medicine is a gift from God. We rushed my sister to a jungle hospital 50 kilometers away, driving over bumpy jungle dirt roads and my sister screamed in pain over every bump we drove over. I still remember this incident like it was yesterday.

The hospital was a shack of a building with chickens walking down the corridor. No one seemed to think anything of that. The doctor operated on my sister, and removed her appendix, informing my mother that we were very fortunate my sister had not died because gangrene had set in, and if her appendix had ruptured, she would have died before we reached the hospital.

This took place in 1958 in the jungle of Brazil. The hospital bill came to $\$ 110$. My parents didn't have any money, let alone that much. The hospital bill, as little as it was by today's standards, could have just as well been a million and ten dollars because my folks simply didn't have the money to pay this bill. My father was an honorable man, and he wanted to pay the bill. He asked the Lord to help him, reminding the Lord, that it would not look good for a missionary who was preaching Jesus, to not be able to pay his bill... a bill that saved his daughter's life.

Without knowing any of this, or what had transpired, the Lord spoke to a dishwasher in Chicago and told him to send \$110 to my parents. He obeyed without as much as a question (what for or why, Lord?) and placed eleven 
ten-dollar cash bills into an envelope and mailed it to my parents. This was in itself a miracle, but the fact that my parents received the money was yet another miracle, because the locals opened all foreign incoming mail, looking for money. They were known to steal money this way, along with magazines that people would occasionally send us. This cash sent from a dishwasher in Chicago made it through, and the dishwasher had no idea that my sister had been rushed to a jungle hospital. The Lord is real, and he still answers prayer and splits the Red Sea. We just have to learn to take him at his word, and trust him that he will provide. He promised he would! Did you know that?

\section{Scripture Analysis of How Faith Can Work in Other People's Lives}

Look at what Jesus had to say about faith in Matthew 6:

${ }^{25}$ “'Therefore I say to you, do not worry about your life, what you will eat or what you will drink; or about your body, what you will put on. Is not life more than food and the body more than clothing? ${ }^{26} \mathrm{Look}$ at the birds of the air, for they neither sow nor reap nor gather into barns; yet your heavenly Father feeds them. Are you not of more value than they? ${ }^{27}$ Which of you by worrying can add one ${ }^{[j]}$ cubit to his ${ }^{[\mathrm{k}]}$ stature? ${ }^{28 \text { "So }}$ why do you worry about clothing? Consider the lilies of the field, how they grow: they neither toil nor spin; ${ }^{29}$ and yet I say to you that even Solomon in all his glory was not ${ }^{[1]}$ arrayed like one of these. ${ }^{30}$ Now if God so clothes the grass of the field, which today is, and tomorrow is thrown into the oven, will he not much more clothe you, $\mathrm{O}$ you of little faith? 31' Therefore do not worry, saying, 'What shall we eat?' or 'What shall we drink?' or 'What shall we wear?' ${ }^{32}$ For after all these things the Gentiles seek. For your heavenly Father knows that you need all these things [Including $\$ 110$ for a hospital bill]. ${ }^{33}$ But seek first the kingdom of God and His righteousness, and all these things shall be added to you. ${ }^{34}$ Therefore do not worry about tomorrow, for tomorrow will worry about its own things. Sufficient for the day is its own trouble (Matthew 6:25-34 NKJV).

In life, we see that a good number of people contumaciously do what they want to do, rather than trust the Lord or seek his will for their lives. Some people may not be conscious of their own willingness to be defiant because the only truth they pursue is what they embrace or agree with.

Jesus said: For where your treasure is, there will your heart be also (Matthew 6:21 NKJV). For those who unapologetically pursue their own course, these words from Jesus, by themselves, simply state a fact, but they don't tell us we should make Jesus the treasure of our hearts. That's up to us! People need to seek the Lord out of their own desire, or at minimum, ask the Lord to show them their need for the Lord and how he can change their lives. Without an understanding of our need for the Lord, simply telling someone that where you treasure lies, there will your heart be also, becomes analogous to telling them you live in a white house or that they drive a blue Toyota. Telling them that 
without spiritual illumination and discernment doesn't impact their thinking. The key to this mystery, and that which follows, is to approach the Lord with sincerity of heart. Ask him to reveal himself to you and show you your need for him. For those of you who may be new to all of this, recognition of our need for the Lord is the work of the Holy Spirit. The Holy Spirit opens our human understanding to this and points us to Jesus. The Lord speaks to us and guides us by his Holy Spirit.

\section{The Analytics of Seeking Truth}

In order for Christianity to have an impact on someone, they must believe there is a God. Most people actually believe this, although many are not quite sure who that God might be. This requires some sincere research or seeking on the part of the person who wants to pursue truth.

People often fail to see or appreciate the intrinsic truth or value of the statement Jesus made that "where your heart is, there will your treasure be also" because they have no personal relationship with the Lord, and/or they never, or perhaps rarely, have ever asked the Lord for his will and guidance, so they have zero clue that the Lord could be their treasure and exceeding great reward. Such a thing has never occurred to them because they are not in pursuit of truth. The true pursuit of truth will lead you to Jesus. What Christians oftentimes want is simply for the Lord to bless their plans and decisions. That's a far cry from saying, Lord, what would you have me do in this matter? Please guide my steps and illuminate my path. Reveal your will to me for my life. You are invited to make the Lord the treasure of your heart.

The solution to all of this is to ask, seek, and knock on the Lord's door for answers. Are you real, Lord? If so, please reveal yourself to me. The good news for those who are on the fence, wondering if Jesus is real, the Lord answers this question in multiple scriptures throughout the Bible. One of the greatest verses in the whole Bible depicts the Lord speaking to us through the prophet Jeremiah. It reads like this: And you will seek Me and find Me when you search for $\mathrm{Me}$ with all your heart (Jeremiah 29:13 KJV). This just might be the greatest promise God has given to the world.

Jesus invites all to ask, seek, and knock on heaven's door for answers and for truth. "Ask, and it will be given to you; seek, and you will find; knock, and it will be opened to you. ${ }^{8}$ For everyone who asks receives, and he who seeks finds, and to him who knocks it will be opened. ${ }^{9}$ Or what man is there among you who, if his son asks for bread, will give him a stone? ${ }^{10} \mathrm{Or}$ if he asks for a fish, will he give him a serpent? ${ }^{11}$ If you then, being evil, know how to give good gifts to your children, how much more will your Father who is in heaven give good things to those who ask Him! (Matthew 7:7-11 NKJV). If you search for the Lord with all your heart, you will find him!

It's not hard to see that our fallen sinful nature impedes us, and we have to learn from failure, that what we want and what we pursue isn't always truth. The 
pursuit of truth ultimately will lead us to Christ, but as Christians, we oftentimes deceive ourselves into thinking what we want is the truth, or what we want is the same thing that Christ wants for our long-term growth and development. We are not all in pursuit of the same thing, let alone the pursuit of the truth. The right prayer can change this.

\section{What Is the Greatest Commandment of All?}

In the gospel of Matthew, we see that the elite religious scholars, priests, and rabbis of that day were not pursuing truth or they would have embraced Jesus. Instead, they conspired to trap Jesus in his words (Matthew 22:15 NIV). Why would anyone want to trap Jesus in his words unless they were against him from the very beginning? This Pharisee plotting scheme became far more nefarious than simply disavowing Jesus as the Jews' Messiah. As Jesus continued his ministry, healing the sick, casting out demon spirits, and raising the dead, the chief priests and the scribes sought how they might kill Him (Luke 22:2), and to that end, the High Priests ultimately used the exculpatory charge of blasphemy to crucify Jesus. How was this possible? Because the religious leaders of that day had no interest in the truth and they were filled with pride, hypocrisy, and they had their own narrative of how they wanted a Messiah to look like and behave.

${ }^{34}$ [After] hearing that Jesus had silenced the Sadducees, the Pharisees got together. ${ }^{35}$ One of them, an expert in the law, (the word "lawyer" is used in KJV)

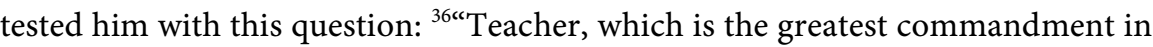
the Law?" ${ }^{37}$ Jesus answered: Love the Lord your God with all your heart and with all your soul and with all your mind. ${ }^{38}$ This is the first and greatest commandment. ${ }^{39}$ And the second is like it: 'Love your neighbor as yourself. ${ }^{[b]}{ }^{40}$ All the Law and the Prophets hang on these two commandments." (Matthew 22:34-40 NIV)

There is an interesting side note to the "great" commandment. It originally came from Moses, not Jesus. Moses first gave this commandment to the children of Israel (Deuteronomy 6:5). It later became known as the Great Commandment. When Jesus was subsequently asked about this, he modified its original wording by adding the word mind to the lexicon of this commandment that already included loving God with all of one's heart, soul, and strength. The Lord wants us to practice critical thinking. Christians need to be Bereans of the Word, rightly dividing the Word because we apply diligent critical thinking effort into studying the Word of God.

After affirming the first Great Commandment (the greatest of all), Jesus then likened it to the second great commandment, that we love our neighbor as ourselves (Matthew 22:39 NKJV). In the gospel of John, Jesus reemphasized this before his heavenly departure, by saying: "A new commandment I give to you, that you love one another; as I have loved you, that you also love one another" (John 13:34 NKJV).

If loving God with all of our being isn't hard enough, in and of itself, consider what else Jesus said: "You have heard that it was said, 'You shall love your 
neighbor and hate your enemy." ${ }^{44}$ But I say to you, love your enemies, bless those who curse you, do good to those who hate you, and pray for those who spitefully use you and persecute you (Matthew 5:43,44 NKJV). If all of this does not break your back, Jesus makes this commandment: Be ye, therefore, perfect, even as your Father which is in heaven is perfect (Matthew 5:48 KJV).

So, there you have it friends. All we have to do is love God with every fiber of our being, love our neighbor, and our enemies, and forgive everyone who has trespassed against us, for if ye forgive not men their trespasses, neither will your Father forgive your trespasses (Matthew 6:15 KJV). Finally, just to cover all the bases, we are to produce righteous fruit, and be perfect, as our Father in heaven is perfect. I want you to get right on this! I am attempting to introduce a little sardonic humor, here, in case you didn't notice. None of this is remotely possible without the Lord's help! It becomes possible to do these impossible things if we ask God to help us, we learn from our failures, and we lean upon the Lord daily for his direction in our lives, taking one day at a time. Overcoming is all about surrendering our own agendas to the will of our father in heaven. It requires honesty and a willingness to die to self. It's no easy thing. But it begins with the pursuit of truth. Jesus is the way, the truth, and the life.

Moses wrote the first five books of the Bible, referred to as the Pentateuch in Christianity, and God gave him the Ten Commandments. There were a whole lot more than just the Ten Commandments to be observed in Judaism. These laws are often referred to collectively as the Torah, or the law. There were 613 different rules and laws to be observed by the Jews (Sands, 2021). Jesus reduced 613 different rules and laws into two simple commandments that even children can understand. Love God with all your might, and love your neighbor as yourself. The second great commandment, by the way, to love your neighbor, encapsulates the Golden Rule. The entire epistemology of successful Christianity can be summarized succinctly with these words: love God; love people!

\section{Living out the Great Commandment in Our Lives}

Most people don't choose to love God with all their heart, soul, strength, and mind. Most people frankly don't even try, or make a serious effort at this. Human indifference comes into play with this, not only because it is such a difficult thing, but also because, in many ways, we are like children who haven't learned self-discipline or the concept of altruism, loving others. We want our own way, just like two-year-old's who throw a fit when their parents tell them no, or the parent takes something away from them. We've all seen the tantrums little children display in the grocery stores. Just like little children who are learning, not every Christian adult is seeking an MVP maturity award from the Lord or a Ph.D. in religious truth. The harsh reality is most people seek man's approval, rather than the Lord's approval. No one is standing in line to become the next John the Baptist, who was beheaded for preaching truth, and Jesus allowed it.

Can you imagine what full commitment might look like if we were never dis- 
ingenuous at any level? For some, full commitment might look like John the Baptist's head on a platter. For those who just want to make it into heaven with the least amount of effort or commitment, their motivational question is not, what more can I do for my Lord, Savior, and King? For some people, their question is, what's the least I can do, and still make it into heaven? I assure you, such folk will not be serving the Lord with all their heart, soul, strength, and mind. Few do. But if you are one of the few who considers giving your all to the Lord, you need to know what you will be facing, and what you will need to do to overcome failure. You will be hated by the world for Christ's sake and persecuted by even your own brothers and sisters (John 15:18,19 NKJV). Sadly, such teaching is rarely heard in churches anymore.

Allow me to share one more anecdotal life experience of my own that illustrates my own child-like immaturity and the lack of experience and desire to walk with God. When I was 19 years old, (barely able to cross the street by myself without an adult holding my hand) I gave some serious reflection and soliloquy to the Great Commandment, that we should love God with all our heart, soul, strength, and mind. It scared the hell out of me. It depressed me because I knew I did not love God with every ounce of my soul. I found that very troubling, but if I had been completely honest with myself at that time, I didn't want to love or serve God with all my heart, soul, and being, and that was even more troubling.

The ugly truth of the matter also involved personal self-doubt over the likelihood that this could ever be a serious possibility for me. It wasn't that I didn't want to live a superficial life that pursued truth and righteousness for 60 minutes on Easter, but rather a matter that I truly lacked the inner capacity or desire to fully serve God with real efficacious profundity with the immaturity I had at that time. At age 19 my hormones and libido were raging, and I struggled with lustful sexual thoughts with nearly every attractive woman I laid my eyes on... and there was a lot of them of every race, creed, and color! The last thing I wanted at age 19 was an unattractive wife that had lots of deep spiritual character, but was not able to wear a bikini because she weighed 350 pounds. Nor did I want the Lord to return and rapture us, before I had a chance to consummate my manhood. I was foolishly terrified the Lord might give me a wife who weighted 350-lbs and had an extra tooth growing out of her forehead. What a horrible misogynistic thought! I assure you, not all 19-year-olds were this evil. Sadly, I was! LOL!

No one can love God at their full potential, love and forgive others, and be perfect as our Heavenly Father without help from the Holy Spirit. Without God's help you will utterly fail. With God's help you will still fail in your flesh, but you will mitigate your failures, be forgiven for your losses, and you will become more mature and godly as you learn how to persevere, overcome, and walk in the Spirit. It's a journey that entails overcoming adversity. Failure is permissible and utilitarian to learning, and forgiveness is attainable! 


\section{The Disingenuous Assertion of Christians Wanting to Be Like Jesus}

We are not all in pursuit of truth or we would all be pursuing Jesus with our whole heart, soul, strength, and mind. One of the most disingenuous things we hear from church leaders and Bible study home group members is that Christians want to be like Jesus. That may sound like a wonderful goal, but I assure you most of global Christendom does not want to be like Jesus, otherwise, their love would change the world, eliminate poverty and hunger, war, and they would all be willing to go to the cross and die to self. Christians would love all children and provide for them, as if they were their very own. Selfishness would come to an end!

Those who profess their desire to be like Jesus rarely manifest this type of divine behavior in their daily lives, or in how they treat others. This author wants to be careful to not paint everyone with the same wide paintbrush, but there are many unloving Christians who treat others worse than those who don't even claim to know or follow Jesus. Christians can be some of the most difficult people there are to love or get along with. There are some folks who wouldn't help you if you were bleeding to death, or go with you to the corner store if the weather was inclement, let alone would they go to the cross.

It has been said many times by worldly people that it isn't Jesus that the non-religious world opposes or hates; it's Christians who misrepresent and dishonor Jesus. There is a sliver of truth to this because many Christians are so hypocritical and unloving that it's easy to hate them, but the truth of this statement is also misleading because the world hates even good Christians and it tends to embrace Christians who tolerate sin and all sorts of evil. As long as Christians are fundamentally just like the rest of the world, the world will accept them. I suppose that being like Jesus is a popular religious narrative or dog whistle that reflects the politically correct religious goal and doctrinal value that we are supposed to have as Christians, but in a world where everyone seems to want political correctness over substance, this phrase symbolizes disingenuous morality and behavioral duplicity, and the assertion simply mirrors inculpatory dishonest rhetoric in most cases.

We have to painfully learn this lesson (and admit to ourselves) that we are not all equally in pursuit of truth. And we don't all want to be like Jesus! Perhaps the more honest thing that some Christians say is that they want to be more like Jesus... but what is also rarely mentioned is the fact that Christians oftentimes don't want to be too much like Jesus. If you are only a little bit like Jesus, you can blend in with the world and be accepted. Can I be a little bit like or Jesus, or a lot like Jesus? Yes! It is important to also note that there are many loving Christians who do the right thing, day in and day out, and treat people right, give to the poor, and stand up for righteousness. Many of these are persecuted for their faith simply because they promote moral values and righteous behavior, and they oppose immorality and refuse to embrace evil. 
The majority of self-identifying Christians will be left behind when the pretribulation rapture occurs, as two are working in the field; one will be taken and the other left behind. Two shall be grinding at the mill; one will be taken and the other left (Matthew 24:40,41 KJV). Why does this happen? Because many are not fully committed, walking in obedience and in full surrender with oil in their lamps. They are not in a state of readiness, looking for the Lord's return. They are lukewarm and they love the world, and all that it offers.

If Christians pursued the Lord with their whole heart, soul, with all their strength, and their mind, the world would hate them and reject them. Jesus said, ${ }^{18}$ "If the world hates you, you know that it hated me before it hated you. ${ }^{19}$ If you were of the world, the world would love its own. Yet because you are not of the world, but I chose you out of the world, therefore the world hates you." ${ }^{20}$ Remember the word that I said to you, "A servant is not greater than his master." If they persecuted me, they will also persecute you (John 15:18,19 NKJV).

Jesus said you will know them by their fruits. A good tree does not produce bad fruit. A bad tree does not produce good fruit (Matthew 7:40,41 KJV). You can be a little bit like Jesus and no one will even know, providing we don't examine their fruits or their camouflaged lives.

If Christians wanted to be a little more like Jesus, they would have simply voted against immoral laws, and pressured their legislators to outlaw and stop the killing of millions of babies that have been murdered by preferential elective abortions that were not necessary to save the mother's life. Christians, Catholics, Jews, and pastors from every denominal faith did nothing and simply looked the other way with indifference for years on end. There was a time in America where there was more godly morality and respect for life. For three consecutive years in 1960,1961 , and 1962, there were only 292 abortions reported in each of those years (Johnston, 2014).

In order to better grasp the pervasive deleterious scope and magnitude of abortion, and the malevolent disregard for human life in the womb, one has to understand that the reporting requirements for abortions in America are not mandated by federal law. Research by the Guttmacher Institute (2021) provides state by state detailed data analysis of abortion reporting requirements each state provides to the Centers for Disease Control (CDC), a national public health agency of the United States federal government. The statistical abortion data each state submits to CDC on how many abortions occurred in their state is entirely based upon a voluntary state-by-state reporting system. Unlike state abortion clinics which must report data to their home state, there are exceptions where some private doctors do not have to report abortions, and there are some states that allow minors to have abortions without any parental consultation. Non-surgical intervention abortions by taking a medical pill usually require no local reporting of any kind, and of course, illegal abortions are never reported.

There have been, and continue to be, untold numbers of illegal abortions. The true number of abortions that take place in America is staggering, and admit- 
tedly under reported. Current average annual estimates of abortions by 1st Choice Pregnancy Resource Center (2020) put the number of abortions at 1 million per year, but these are based solely on voluntary state reporting to CDC. Statistical research shows that from 1960 to 1974 there were 2,271,763 legal abortions in the United States. If we completely exclude all abortions from the 60s to 1974 , over 2 million of them, we see that from 1975 to 2013 there were a whopping $51,157,600$ reported abortions in the United States that have been document (Johnston, 2014). Once again, these staggering numbers only reflect legal abortions that were voluntarily reported to CDC. Based on the current estimate of 1 million annual abortions being performed every year, we can project another 8 million abortions which will have been performed from 2013 through 2021. Adding these 8 million abortions to the previous total of 51,157,600 abortions from 1975 to 2013, brings the current total up to 59 million deaths in 2021!

Some estimates put the current annual number of abortions in the 800,000-range category, but the true number far exceed these numbers because the data only counts voluntary reporting that is submitted to CDC from states that don't all submit full or accurate reports, and some don't report at all. Moreover, the low data estimates of 800,000 do not account for many juvenile abortions, nor illegal abortions. Some statistical data charts only report up to 2019. If we consider the average number of documented abortions for many consecutive years in the 70s and 80 s was over 1.5 million each year, then it should be no shock that the current average for the last 8 years is approximately 1 million per year. These estimates are considered to be conservative figures. The math is simple. From 1960 through 2021 the conservative numbers add up to over 59 million deaths!

More babies have been killed through abortions in the United States than all those killed in battle from all the wars that the US has ever fought, starting in 1775 through 2021. Based on government-provided data and other sources, the combined total number of Americans who died in US wars totals approximately 2.8 million (Wikipedia, 2021). The number of babies killed through abortion from 1960 to date totals over 59 million! As a nation, Americans have permitted the death of millions of innocent unborn. The Church, as a whole, has allowed this. There is much that America needs to repent for in allowing this horrific slaughter of innocence.

The National Archives.gov/founding-docs memorializes the unanimous Declaration of Independence in Congress on July 4, 1776, with these indelible words: "We hold these truths to be self-evident, that all men are created equal, that they are endowed by their Creator with certain unalienable rights that among these are Life, Liberty, and the pursuit of Happiness." America's national immorality has obfuscated the sanctity of these words with abortion (America's Founding Documents, 1776).

There is also a great irony in all of this which represents a further abomination of law and morality. In most states, if a criminal shoots and kills a pregnant mother (like in a bank robbery) the suspect can be charged with double homicide because the baby and the mother are both counted in the criminal com- 
plaint. We throw such justice entirely out the window if one simply walks into an abortion clinic and has the baby aborted. The baby is simply killed. Does any honest person who is not completely delusional think that God would not consider this to be murder? We are not all in pursuit of spiritual truth, nor do we all love God with all our heart, soul, strength, and mind. Jesus commanded us to love one another. The killing of the unborn is not a permissible exception.

Then there is the issue of money and stewardship when we explore the disingenuous stated goal of Christians who claim they want to be like Jesus. The Bible states that the love of money is the root of all evil (1 Timothy 6:10 KJV)

If Christians all wanted to be like Jesus they would not cling to their money like it was more precious than life itself. They would give more of it to the poor, the homeless, and the hungry. Christians would start tithing for starters, and pastors would stop preaching the spurious tickle-my-ears prosperity gospel that God just wants to bless his elect with money, expensive homes, jewelry, and yachts, without any personal sacrifice, character development, or repentance.

The global church as a whole, with some exceptions, has not done enough to help the poor, the hungry, and homeless. ${ }^{14}$ What good is it, my brothers and sisters, if someone claims to have faith but has no deeds? Can such faith save them?

${ }^{15}$ Suppose a brother or a sister is without clothes and daily food. ${ }^{16}$ If one of you says to them, "Go in peace; keep warm and well fed," but does nothing about their physical needs, what good is it? ${ }^{17}$ In the same way, faith by itself, if it is not accompanied by action, is dead (James 2:14-17 NIV).

Years of research consistently show that only $12 \%$ of church members give any amount of money to their church to support the work of God. Historically, this means $88 \%$ of church members give nothing at all. Present-day church pastors who talk with each other about their church's finances will confirm only $12 \%$ of their members give any amount to their church. Only 3.5\% to $6 \%$ of church members actually tithe according to its biblical definition (Sider, 2005).

Learning how to truly love God and our fellow neighbor (who may be unlovable) comes from a heart of altruism, forgiveness, obedience, full surrender, maturity, and wisdom. Greater faith comes from life experience, being tempted in the wilderness like Jesus was, while learning to fully surrender and lean on the Lord, and recognize his voice and accept the Lord's direction and pruning in our lives.

Our hubris permits us to think we are doing pretty well because we compare ourselves to others. We didn't rob a bank, and we gave $\$ 20$ to the Red Cross, but the children we allowed to be murdered were quietly disposed of as biologic hazardous waste material in sealed hermetical bags.

\section{Why Are Principles So Important?}

Generally speaking, good principles (not to be confused with evil principles) are enduring concepts of truth that tend to be universal in nature, and not limited in scope to some small geographic group of people who lived a long time ago. The 
Great Commandment, for example, isn't a truth that only applied to the Mosaic Israelite Jews 3400 years ago. The Great Commandment applies to all of us today. Principles don't have expiration dates on them like milk we purchase at the market. Principles are not limited in scope by their degree of profundity. For example, telling the truth is a behavioral truth we hopefully want our children to learn. Telling the truth becomes a principle by which people choose to live by. The principle of telling the truth becomes significant when no one sees what we have done, and lying about it becomes a possibility, one we might be able to get away with, but we choose to tell the truth, even when no one saw our behavior. God saw it!

Principles of truth are concepts that typically apply almost everywhere. People who put their trust in us expect us to tell truth all the time, not just on certain days of the week. There are behavioral principles we can choose to live by, but there are also scientific principles, like the law of gravity found in the laws of physics. For those who go deep enough, the laws of physics become mere guidelines, not absolute laws. Faith in God can change everything. We find an example of this in the book of Matthew, but the Bible has scores of other examples where the principle of faith changed the ground conditions. In Matthew 14 we read this account of Jesus walking on the Sea of Galilee.

${ }^{25}$ Now in the fourth watch of the night Jesus went to them, walking on the sea. ${ }^{26} \mathrm{And}$ when the disciples saw him walking on the sea, they were troubled, saying, "It is a ghost!" And they cried out for fear. ${ }^{27}$ But immediately Jesus spoke to them, saying, ${ }^{[c] "}$ "Be of good cheer! ${ }^{[\mathrm{d}]}$ It is I; do not be afraid." ${ }^{28}$ And Peter answered him and said, "Lord, if it is you, command me to come to you on the water." ${ }^{29}$ So He said, "Come." And when Peter had come down out of the boat, he walked on the water to go to Jesus. ${ }^{30} \mathrm{But}$ when he saw ${ }^{[\mathrm{e}]}$ that the wind was boisterous, he was afraid; and beginning to sink he cried out, saying, "Lord, save me!" ${ }^{31}$ And immediately Jesus stretched out his hand and caught him, and said to him, "O you of little faith, why did you doubt?" ${ }^{32}$ And when they got into the boat, the wind ceased (Matthew 14:25-32 NKJV).

For a short time, Peter walked on the water too, and defied the laws of physics, until he took his eyes off Jesus and was overcome by fear.

There are, of course, exceptions and limitations to most things in life. Within this context, enduring principles can be either righteous or evil in their thematic sphere of influence. For this reason, it is important for readers to understand that biblical spiritual principles are good things which we should endeavor to follow or apply to our lives. In sharp contrast, there are principles of darkness and evil. For example, Satan can use principles that embrace human weakness to tempt us, or fool us into doing something that is contrary to what God would have us do. Satan is the father of all lies. He can appear disguised as an angel of light and say something that is partially true, but his words end with a lie. We teach students in grade school that a sentence is either completely true, or it's false. Thus, deception is a principle that Satan regularly uses against us. You should question and distrust everything Satan whispers to you, because he is ul- 
timately a liar, even if some small component of what he says happens to be true. Satan offers humanity principles of darkness which ultimately end with eternal death.

Conversely, righteous principles lead us into the light, sustaining life, and produce spiritual efficacy. Question all things to make sure they stand up to righteous truth, under the scrutiny of God's bright light and written Word. Honesty is an enduring principle that doesn't provide an exception for us to lie on some given day of the week. Faith is an enduring principle that God honors and rewards. Fire is a force that can be used to warm your home or burn it down. Ask the Lord for discernment.

\section{Why Can't We Just Depend on Capitalism or Socialism to Solve Global Problems?}

Capitalism in the hands of righteous governments can produce economic prosperity when it is intentionally designed to benefit all the people of its kingdom, but like anything mankind does, it can be perverted and abused. Governments run by wicked men have all failed over the centuries. The only lasting government that will reign for all eternity is the government led by Jesus. The government of Jesus is not a democracy wherein we vote to accept or reject his leadership. Jesus is a righteous King that we, his followers, are willing to serve.

Present-day conventional capitalism is all about making a profit that produces and ensures ongoing prosperity. It promotes and rewards productivity which ensures its own survival, without regard for what is morally right or economically right. Without a godly form of righteousness, capitalism becomes all about money, power, and survival, and selfish wealth. The United States has been an example of this. The US became the most prosperous powerful nation on earth, but her apostasy has led to her own destruction and demise. Without godly moral leadership, America becomes a deep state of corruption and abusive power that is bringing utter institutional pervasive failure. America is currently divided and on the brink of collapse. In the final analysis, blame should not be ascribed to a single political administration, but rather the people who collectively elect their leaders, and thereafter tolerate ungodliness and pervasive evil.

\section{Avoiding Hubristic Spiritual Assumptions and Decisions}

When important decisions need to be made, don't automatically assume you know the mind of God. Seek his will and guidance humbly and wait upon the Lord for an answer. Trust in the Lord with all thine heart; and lean not unto thine own understanding. In all thy ways acknowledge him and he shall direct thy paths (Proverbs 3:5,6 KJV). Keep an open mind for the Lord to do or say the unexpected. The Lord says, "For as the heavens are higher than the earth, so are my ways higher than your ways, and my thoughts than your thoughts" (Isaiah 55:9 KJV). When things look fixed or impossible, trust is in the Lord. The Lord can do the impossible and he still splits the Red Sea. 
When the Lord opens a door for you, you won't have to beat the door down to get in or be accepted. The door will open without you having to strain to make it happen. It happens effortlessly, even if there is some unseen opposition or resistance. The enemy won't be able to stop or close any door which the Lord opens for you. Likewise, if others open the door for you, don't automatically assume this is the Lord's will. Pray about it and seek the Lord's confirmation. Be willing to take or leave any offer that man gives you. You need to feel peace and assurance that you are to enter the door presented to you. All doors are not from the Lord.

Seeking the perfect will of God requires honesty on your part and a desire for truth that comes from the Lord. Avoid that which tickles your ears that you want to hear, or that which you desire and want to attain. Human nature is such that we can't always trust ourselves to fully know what some of our hidden motivations might be. Remember, the heart is deceitful above all things, and desperately wicked; who can know it? (Jeremiah 17:9 KJV) The fining pot is for silver and the furnace for gold: but the LORD trieth the hearts (Proverbs 17:3 KJV). Let the Lord test the matter and examine your heart. Don't assume what you want is what the Lord wants.

In seeking guidance or direction from the Lord, we oftentimes simply want the Lord to bless our will and choices, and the thing which we want, and we completely forget that the human heart is deceitful above all things, AND desperately wicked! This is a truth that few Christians want to acknowledge. It's a very uncomfortable truth.

For this reason, we can't start out with the presumption of innocence, like we do in criminal courts. In the court of heaven, we must assume that man's heart is deceitful and desperately wicked. Moreover, the Lord can produce evidence to show this, and prove what we don't want to know or hear. We have to begin by acknowledging that we may not even want to know the truth, so please help me Lord to want truth, and seek truth, and not just any so-called truth, but your truth, Lord. Help me Lord to want to do the right thing, because much of time I don't honestly want to do the right thing. Circumcise my heart Lord so I will want to do the right thing in your eyes.

Man's heart is the weak link. Jesus said: For out of the heart proceed evil thoughts, murders, adulteries, fornications, thefts, false witness, blasphemies (Matt 15:19 NKJV). We can't assume we want the truth or the right thing. Jesus said, "For where your treasure is, there your heart will be also" (Matthew 6:21 NKJV). If we don't love the Lord our God with all our heart, with all our soul, and with all our strength, and with our mind, then the Lord is not the full treasure of our heart. We have to ask God to help us with this, and give us a new heart, wherein Jesus becomes number one of all things important to us.

\section{Conclusion/Commentary}

What Do Successful Christians Look Like? 
What behaviors do they practice? Successful men and women who follow Jesus are committed to truth, obedience, repentance, service, and they ask tough questions of themselves and of God. How am I doing, Lord? Are all my ways pleasing in our sight? Where do I need to make modifications or adjustments in my life to better serve you? Successful Christians love God will all their heart, soul, strength, and mind. This is the first Great Commandment. The measuring stick that allows us to draw such a conclusion is successful Christians love their neighbors and manifest love and compassion for people they have never met. It's the second great commandment-love your neighbor-that enables us to know with certainty that Christians truly love God. It is impossible to love God without loving others.

If someone says, "I love God", and hates his brother, he is a liar; for he who does not love his brother whom he has seen, how can he love God whom he has not seen? (1 John 4:20 NKJV). Jesus said: a new commandment I give you that you love one another. That means the rest of the world. We are all neighbors.

Successful Christians this author has seen over a lifetime who inspired me are constantly seeking the Lord's truth and perfect will, and they live a disciplined life of obedience, full surrender, and humility. Their lives produce much fruit. They accept the Lord's pruning in their lives. Successful Christians manifest the fruits of the Spirit: love, joy, peace, patience, kindness, goodness, faithfulness, gentleness, self-control; against such things, there is no law (Galatians 5:22,23 NASB).

\section{Successful Christians produce righteous fruit}

The True Vine (The gospel of John)

"I am the true vine, and my father is the vinedresser. ${ }^{2}$ Every branch in me that does not bear fruit he ${ }^{[a]}$ takes away; and every branch that bears fruit he prunes, that it may bear more fruit. ${ }^{3}$ You are already clean because of the word which I have spoken to you. ${ }^{4}$ Abide in me, and I in you. As the branch cannot bear fruit of itself, unless it abides in the vine, neither can you, unless you abide in me.

5"I am the vine, you are the branches. He who abides in me, and I in him, bears much fruit; for without me you can do nothing. ${ }^{6}$ If anyone does not abide in me, he is cast out as a branch and is withered; and they gather them and throw them into the fire, and they are burned. ${ }^{7}$ If you abide in me, and my words abide in you, you ${ }^{[b]}$ will ask what you desire, and it shall be done for you. ${ }^{8}$ By this My Father is glorified, that you bear much fruit; so you will be my disciples.

Love and Joy Perfected

9"As the father loved me, I also have loved you; abide in my love. ${ }^{10}$ If you keep my commandments, you will abide in my love, just as I have kept my Father's commandments and abide in his love.

${ }^{11}$ “These things I have spoken to you, that my joy may remain in you, and that your joy may be full. ${ }^{12}$ This is my commandment, that you love one another as I have loved you. ${ }^{13}$ Greater love has no one than this, than to lay down one's life for his friends. ${ }^{14}$ You are my friends if you do whatever I command you. ${ }^{15}$ No 
longer do I call you servants, for a servant does not know what his master is doing; but I have called you friends, for all things that I heard from my father I have made known to you. ${ }^{16} \mathrm{You}$ did not choose me, but I chose you and appointed you that you should go and bear fruit, and that your fruit should remain, that whatever you ask the Father in my name he may give you. ${ }^{17}$ These things I command you, that you love one another (John 15:1-17 NKJV).

\section{Epilogue-author's closing thoughts}

Where are things headed in the world right now? Perhaps you've noticed, as many of us have, the world is in a very unstable, precarious position, not only with the recent COVID-19 pandemic with its variants but with every aspect of life being impacted or altered. There are global threats of war, further pandemic fears, and food shortages are beginning to occur all around the world, even in countries that we think of as being prosperous and self-sufficient. These eschatological end-time conditions are described in Revelation chapter 6, describing events to come that depict the start of the 7-year tribulation. The world seems to collectively be going to hell in a handbasket, having lost its ethical commitment and moral compass to convivial living. Crime and violence are at an all-time high. Mankind's moral compass is a spiritual matter, one that is presently dying. Apostasy, crime, and great evil are taking place all around us, just as predicted in the Bible. The end of days is fast approaching which will take us into the 7-year tribulation as described in the biblical books of Daniel, Matthew, and Revelation. This is the time for all people to make things right with their creator. Our destiny is at stake.

\section{Conflicts of Interest}

The author declares no conflicts of interest regarding the publication of this paper.

\section{References}

1st Choice Pregnancy Resource Center (2020). How Can I Stop Abortion? https://firstchoiceprc.com/pro-life-movement?gclid=Cj0KCQjwt 6LBhDlARIsAIPRQcJYIgSeyiHgLjNvdmoIrcltP0wV_VJgRvn_drN35sp90Aqfe9T32jsa AgmYEALw_wcB

America's Founding Documents (1776). Declaration of Independence: A Transcription. https://www.archives.gov/founding-docs/declaration-transcript

Guttmacher Institute (2021). Abortion Reporting Requirements. https://www.guttmacher.org/state-policy/explore/abortion-reporting-requirements

Johnston, R. Wm. (2014). United States Abortion Rates, 1960-2013. https://www.johnstonsarchive.net/policy/abortion/graphusabrate.html

Sands, L. M. (2021, November 15). What is the Mosaic Law? My Law Questions.com. https://www.mylawquestions.com/what-is-the-mosaic-law.htm

Sider, R. J. (2005). The Scandal of the Evangelical Conscience (pp. 20-21). Baker Books Publishing.

The Top 10 Best-selling Books of All Time (2021). 
https://www.alltopeverything.com/top-10-best-selling-books-of-all-time/

Wikipedia (2021, November 14). United States Military Casualties of War. https://en.wikipedia.org/wiki/United_States_military_casualties_of_war 